\title{
A remote sensing model to estimate ecosystem respiration in Northern China and the Tibetan Plateau
}

\author{
Yanni Gao ${ }^{\mathrm{a}, \mathrm{b}}$, Guirui Yu ${ }^{\mathrm{a}, *}$, Shenggong $\mathrm{Li}^{\mathrm{a}}$, Huimin Yan ${ }^{\mathrm{a}, *}$, Xianjin Zhu ${ }^{\mathrm{a}, \mathrm{c}}$, Qiufeng Wang ${ }^{\mathrm{a}}$, \\ Peili Shi ${ }^{\mathrm{a}}$, Liang Zhao ${ }^{\mathrm{d}}$, Yingnian Li ${ }^{\mathrm{d}}$, Fawei Zhang ${ }^{\mathrm{d}}$, Yanfen Wang ${ }^{\mathrm{c}}$, Junhui Zhang ${ }^{\mathrm{e}}$ \\ ${ }^{a}$ Synthesis Research Center of Chinese Ecosystem Research Network, Key Laboratory of Ecosystem Network Observation and Modeling, Institute of \\ Geographic Sciences and Natural Resources Research, Chinese Academy of Sciences, Beijing 100101, China \\ b State Key Laboratory of Environmental Criteria and Risk Assessment, Chinese Research Academy of Environmental Sciences, Beijing 100012, China \\ c University of Chinese Academy of Sciences, Beijing 100049, China \\ ${ }^{\mathrm{d}}$ Northwest Institute of Plateau Biology, Chinese Academy of Sciences, Xining 810001, China \\ e Institute of Applied Ecology, Chinese Academy of Sciences, Shenyang 110016, China
}

\section{A R T I C L E I N F O}

\section{Article history:}

Received 12 May 2014

Received in revised form 27 February 2015

Accepted 2 March 2015

Available online 22 March 2015

\section{Keywords:}

Ecosystem respiration

Gross primary production

Temperature

MODIS data

ChinaFLUX

PCM

\begin{abstract}
A B S T R A C T
Ecosystem respiration $\left(R_{\mathrm{e}}\right)$ is rarely quantified from remote sensing data because satellite technique is incapable of observing the key processes associated with soil respiration. In this study, we develop a Remote Sensing Model for $R_{\mathrm{e}}$ (ReRSM) by assuming that one part of $R_{\mathrm{e}}$ is derived from current photosynthate with the respiratory rate coupling closely with gross primary production (GPP), and the other part of $R_{\mathrm{e}}$ is derived from reserved ecosystem organic matter (including plant biomass, plant residues and soil organic matter) with the respiratory rate responding strongly to temperature change. The ReRSM is solely driven by the Enhanced Vegetation Index (EVI), the Land Surface Water Index (LSWI) and the Land Surface Temperature (LST) from MODIS data. Multi-year eddy $\mathrm{CO}_{2}$ flux data of five vegetation types in Northern China and the Tibetan Plateau (including temperate mixed forest, temperate steppe, alpine shrubland, alpine marsh and alpine meadow-steppe) were used for model parameterization and validation. In most cases, the simulated $R_{\mathrm{e}}$ agreed well with the observed $R_{\mathrm{e}}$ in terms of seasonal and interannual variation irrespective of vegetation types. The ReRSM could explain approximately $93 \%$ of the variation in the observed $R_{\mathrm{e}}$ across five vegetation types, with the root mean square error (RMSE) of $0.04 \mathrm{~mol} \mathrm{C} \mathrm{m}^{-2} \mathrm{~d}^{-1}$ and the modeling efficiency (EF) of 0.93. Model comparison showed that the performance of the ReRSM was comparable with that of the RECO in the studied five vegetation types, while the former had much fewer parameters than the latter. The ReRSM parameters showed good linear relationships with the mean annual satellite indices. With these linear functions, the ReRSM could explain approximately $90 \%$ of the variation in the observed $R_{\mathrm{e}}$ across five vegetation types, with the RMSE of $0.05 \mathrm{~mol} \mathrm{C} \mathrm{m}^{-2} \mathrm{~d}^{-1}$ and the EF of 0.89 . These analyses indicated that the ReRSM is a simple and alternative approach in $R_{\mathrm{e}}$ estimation and has the potential of estimating spatial $R_{\mathrm{e}}$. However, the performance of ReRSM in other vegetation types or regions still needs a further study.
\end{abstract}

(c) 2015 Elsevier B.V. All rights reserved.

\section{Introduction}

Net ecosystem $\mathrm{CO}_{2}$ exchange (NEE) is one of the main drivers for interannual variation in atmosphere $\mathrm{CO}_{2}$ concentration (Trumbore, 2006). NEE is a small difference between two large fluxes of gross primary production (GPP) and ecosystem respiration $\left(R_{\mathrm{e}}\right)$. Accurate

\footnotetext{
* Corresponding authors at: Institute of Geographic Sciences and Natural Resources Research, Chinese Academy of Sciences, 11A, Datun Road, Chaoyang District, Beijing 100101, China. Tel.: +861064889432.

E-mail addresses: yugr@igsnrr.ac.cn (G. Yu), yanhm@igsnrr.ac.cn (H. Yan).
}

estimation of the spatio-temporal variation in NEE depends on the robust estimates of GPP and $R_{\mathrm{e}}$.

Remote sensing (RS) technology has been used as a major tool in quantifying carbon balance of ecosystems at regional and global scales because it monitors ecosystem structure at high temporal and spatial resolution (Running et al., 2004; Rahman et al., 2005). There are various satellite-driven GPP models for estimating spatial GPP distribution from remote sensing data (e.g., Xiao et al., 2004; Running et al., 2004; Gitelson et al., 2006, 2012; Yuan et al., 2007; Sims et al., 2008; Wu et al., 2010). Yet, we lack similar methods for $R_{\mathrm{e}}$ estimation.

Ecosystem respiration is composed of different components that are determined by different mechanisms and factors. It is 
difficult for satellite technology to monitor various respiratory processes, especially those in the soil (Valentini et al., 2000; Running et al., 2004; Olofsson et al., 2008; Xiao et al., 2008; Tang et al., 2012), which limit the application of remote sensing data in $R_{\mathrm{e}}$ estimation. However, $R_{\mathrm{e}}$ showed close relationships with easily satellite-retrieved GPP (e.g., Knohl et al., 2005; Tang et al., 2005; Moyano et al., 2007, 2008; Larsen et al., 2007; Bahn et al., 2008; Gomez-Casanovas et al., 2012; Huang and Niu, 2013) and temperature (e.g., Lloyd and Taylor, 1994; Frank et al., 2002; Reichstein et al., 2003; Bond-Lamberty and Thomson, 2010) in most of ecosystems, and upon these relationships some empirical or semi-empirical satellite-driven $R_{\mathrm{e}}$ models were developed and validated at the plot or regional scale (Vourlitis et al., 2003; Gilmanov et al., 2005; Rahman et al., 2005; Schubert et al., 2010; Jägermeyr et al., 2014). However, extensive studies reported that the responses to GPP and temperature varied among the $R_{\mathrm{e}}$ components (e.g., Gaumont-Guay et al., 2008; Kuzyakov and Gavrichkova, 2010), and the current satellite-driven $R_{\mathrm{e}}$ models almost all neglected these differences. Therefore, we will develop a new Remote Sensing Model for $R_{\mathrm{e}}$ (ReRSM) based on the different responses of $R_{\mathrm{e}}$ components to the variations in GPP and temperature. Long-term eddy $\mathrm{CO}_{2}$ flux data of five vegetation types (located in Northern China and the Tibetan Plateau) from the ChinaFLUX were used to assess the model performance. We also compared the estimated accuracy of the ReRSM with that of the RECO, which was a totally satellite-driven $R_{\mathrm{e}}$ model (Jägermeyr et al., 2014).

\section{Materials and methods}

\subsection{Description of the ReRSM}

Ecosystem respiration is mainly composed of five components (Fig. 1). They are plant growth respiration $\left(R_{\mathrm{g}}\right)$ and maintenance respiration $\left(R_{\mathrm{m}}\right)$ belonging to autotrophic respiration $\left(R_{\mathrm{a}}\right)$, and rhizomicrobial respiration $\left(R_{\mathrm{rhi}}\right.$, i.e., microbial respiration of rhizodeposits derived from living roots), microbial respiration of plant residues $\left(R_{\mathrm{res}}\right)$ and SOM decomposition $\left(R_{\mathrm{SOM}}\right)$ belonging to heterotrophic respiration $\left(R_{\mathrm{h}}\right)$.

$R_{\mathrm{e}}=R_{\mathrm{g}}+R_{\mathrm{m}}+R_{\mathrm{rhi}}+R_{\mathrm{res}}+R_{\mathrm{SOM}}$
It was reported that the substrates for plant growth respiration $\left(R_{\mathrm{g}}\right)$ (Amthor, 2000; Piao et al., 2010; Mahecha et al., 2010; Chapin et al., 2011) and rhizomicrobial respiration $\left(R_{\text {rhi }}\right)$ (Kuzyakov and Cheng, 2001, 2004; Dilkes et al., 2004; Heinemeyer et al., 2006, 2007; Moyano et al., 2007, 2008; Gaumont-Guay et al., 2008; Kuzyakov and Gavrichkova, 2010; Mahecha et al., 2010) are both derived from current photosynthate, and their respiratory rates couple closely with GPP. During the process of plant photosynthesis, growth respiration $\left(R_{\mathrm{g}}\right)$ consumes some photosynthate to provide energy for satisfying growth demand. At the same time, part of photosynthate is transferred into rhizosphere soil at high rate in the form of root exudates, which can be rapidly utilized by rhizosphere microorganisms $\left(R_{\text {rhi }}\right)$ (Kuzyakov and Cheng, 2001, 2004; Dilkes et al., 2004; Kuzyakov and Gavrichkova, 2010). Thus, we defined the components of $R_{\mathrm{g}}$ and $R_{\mathrm{rhi}}$ as GPP-derived respiration $\left(R_{\mathrm{GPP}}\right)$, and assumed that $R_{\mathrm{GPP}}$ can be represented by a fraction of GPP $(a)$.

$R_{\mathrm{GPP}}=R_{\mathrm{g}}+R_{\mathrm{rhi}}=a \times \mathrm{GPP}$

The substrates for plant maintenance respiration $\left(R_{\mathrm{m}}\right)$ (Amthor, 2000; Chapin et al., 2011; Kuzyakov and Gavrichkova, 2010), microbial respiration of plant residues $\left(R_{\mathrm{res}}\right)$ (Waksman and Gerretsen, 1931; Zhou et al., 2013) and soil organic matter (SOM) decomposition $\left(R_{\text {SOM }}\right)$ (Bader and Cheng, 2007; Heinemeyer et al., 2007; Moyano et al., 2007, 2008; Gaumont-Guay et al., 2008) are separately derived from plant biomass, plant residues and SOM, and their respiratory rates respond strongly to variation in temperature under no water-limited conditions. Since plant biomass, plant residues and SOM are the organic matters that are stored in the ecosystems over a long term period, we defined them as reserved ecosystem organic matter (EOM) and their corresponding respiratory components as EOM-derived respiration $\left(R_{\mathrm{EOM}}\right)$. If we assumed that the differences among the responses of $R_{\mathrm{m}}, R_{\text {res }}$ and $R_{\mathrm{SOM}}$ to the variation in temperature are negligible and employed the widely used Lloyd and Taylor model (Lloyd and Taylor, 1994) to represent the temperature effect, $R_{\mathrm{EOM}}$ can be expressed as follows:

$$
R_{\mathrm{EOM}}=R_{\mathrm{m}}+R_{\mathrm{res}}+R_{\mathrm{SOM}}=R_{\mathrm{ref}} \times e^{E_{0} *\left(1 /\left(T_{\mathrm{ref}}-T_{0}\right)-1 /\left(T+273.15-T_{0}\right)\right)}
$$

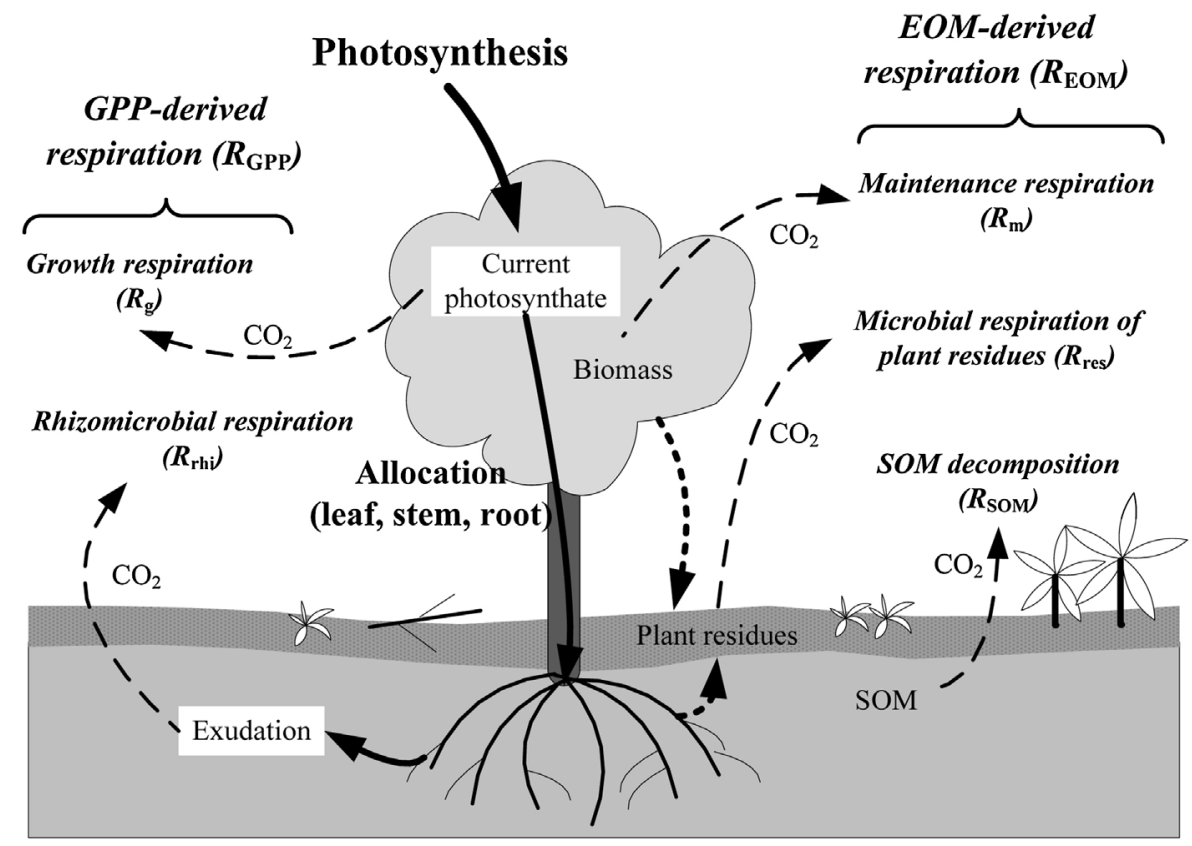

Fig. 1. Components of ecosystem respiration. SOM, soil organic matter; EOM, reserved ecosystem organic matter, including plant biomass, plant residues and SOM. 
where $R_{\text {ref }}$ is the EOM-derived respiration $\left(\mathrm{mol} \mathrm{C} \mathrm{m}^{-2} \mathrm{~d}^{-1}\right)$ at the reference temperature, $E_{0}$ is the activation energy kind of parameter (K), $T$ is temperature $\left({ }^{\circ} \mathrm{C}\right), T_{\text {ref }}$ is the reference temperature, which is set to be $288.15 \mathrm{~K}\left(15^{\circ} \mathrm{C}\right), T_{0}$ is the minimum temperature for respiration, which is set to be $227.13 \mathrm{~K}\left(-46.02{ }^{\circ} \mathrm{C}\right)$.

Incorporating Eq. (2) with Eq. (3), we obtain a general form of the ReRSM as follows:

$R_{\mathrm{e}}=a \times \mathrm{GPP}+R_{\mathrm{ref}} \times e^{E_{0} \times((1 / 61.02)-(1 / T+46.02))}$

The second term in Eq. (4) is the EOM-derived respiration $\left(R_{\mathrm{EOM}}\right)$. While the study reported that the annual maximum LST ( LST $_{\text {max }}$ ) from the Aqua/MODIS sensor increases faster than the site-observed maximum air temperature $\left(T_{\max }\right)$ as temperature increases (Mildrexler et al., 2011), the LST from the Terra/MODIS sensor was reported to correlate closely with the air temperature during daytime, nighttime and mean of the both (e.g., Sims et al., 2008; Ueyama et al., 2010). In our studied sites, the average of daytime LST and nighttime LST from the Terra/MODIS sensor also had a close relationship with the corresponding air temperature, with $r^{2}$ as high as to 0.91 and regression line approximating 1:1 line (Fig. S1). Since the purpose of this study was developing a totally satellite-driven $R_{\mathrm{e}}$ model and to keep the model more operationally, we use the average of daytime LST and nighttime LST from the Terra/MODIS sensor as a fist approximation of $T$ in Eq. (4) in this version of the ReRSM. Then, $R_{\mathrm{EOM}}$ can be expressed as follows:

$R_{\mathrm{EOM}}=R_{\mathrm{ref}} \times e^{E_{0} \times((1 / 61.02)-(1 / \mathrm{LST}+46.02))}$

The first term in Eq. (4) is the GPP-derived respiration $\left(R_{\mathrm{GPP}}\right)$. We have developed a satellite-driven Photosynthetic Capacity Model (PCM) to estimate the dynamic change in GPP, which is solely driven by the Enhanced Vegetation Index (EVI) and the Land Surface Water Index (LSWI) (Gao et al., 2014).

$\mathrm{GPP}=\mathrm{PC}_{\max } \times \mathrm{EVI}_{\mathrm{S}} \times W_{\mathrm{s}}$

where $\mathrm{PC}_{\max }$ represents the maximum photosynthetic capacity $\left(\mathrm{molC} \mathrm{m}^{-2} \mathrm{~d}^{-1}\right.$ ) for each vegetation type or site, $\mathrm{EVI}_{\mathrm{S}}$ indicates the variability of photosynthetic capacity, the product of $\mathrm{PC}_{\max }$ and $\mathrm{EVI}_{\mathrm{S}}$ stands for the photosynthetic capacity $\left(\operatorname{molCm} \mathrm{m}^{-2} \mathrm{~d}^{-1}\right)$, and $W_{\mathrm{s}}$ represents the water conditions which down-regulates the photosynthetic capacity. The values of $\mathrm{EVI}_{\mathrm{s}}$ and $W_{\mathrm{s}}$ are separately calculated from EVI and LSWI, and the detailed equations refer to Gao et al. (2014).

In this version of the ReRSM, we chose the PCM as a confident surrogate for GPP in Eq. (4), and $R_{\mathrm{GPP}}$ can be expressed as follows:

$R_{\mathrm{GPP}}=a \times \mathrm{PC}_{\max } \times \mathrm{EVI}_{\mathrm{s}} \times W_{\mathrm{s}}$

Merging Eq. (5) with Eq. (7), we can gain a solely satellite-driven $R_{\mathrm{e}}$ model:

$R_{\mathrm{e}}=a \times \mathrm{PC}_{\max } \times \mathrm{EVI}_{\mathrm{S}} \times W_{\mathrm{s}}+R_{\mathrm{ref}} \times e^{E_{0} \times((1 / 61.02)-(1 / \mathrm{LST}+46.02))}$

Since soil moisture was reported to limit the rate of respiration at drought or severe drought regions through affecting the accessibility of respiratory substrate and the activity of relevant biological enzymes (Reichstein et al., 2002; Rey et al., 2002; Davidson and Janssens, 2006; Matías et al., 2012), we developed a variant of Eq. (8) with $W_{\mathrm{s}}$ multiplying the $R_{\mathrm{EOM}}$ part.

$R_{\mathrm{e}}=a \times \mathrm{PC}_{\max } \times \mathrm{EVI}_{\mathrm{S}} \times W_{\mathrm{s}}+R_{\mathrm{ref}} \times e^{E_{0} \times((1 / 61.02)-(1 / \mathrm{LST}+46.02))} \times W_{\mathrm{s}}$

The comparison showed that the estimated accuracy of Eq. (9) was nearly the same as Eq. (8) during either the whole year (Table $\mathrm{S} 1$ ) or the growing season (Table S2). Due to lack of a general equation in expressing the impact of soil moisture on $R_{\mathrm{e}}$, we therefore chose Eq. (8) as the first version of the ReRSM. $a, \mathrm{PC}_{\max }, R_{\text {ref }}$ and
$E_{0}$ are the model parameters, which expressed the variation of $R_{\mathrm{e}}$ across sites; EVI, LSWI and LST are the model variables, which indicated the temporal variation of $R_{\mathrm{e}}$. The value of $\mathrm{PC}_{\max }$ in each vegetation type is derived from Gao et al. (2014). The theoretical assumptions and key equations related to the ReRSM are presented in Fig. 2.

\subsection{Flux data}

The eddy $\mathrm{CO}_{2}$ flux data from the ChinaFLUX natural vegetation types located in Northern China and the Tibetan Plateau were chosen to assess the performance of the model in this study (Fig. 3). There are five vegetation types, including temperate mixed forest (the broad-leaved Korean pine mixed forest in the Changbai Mountains, MF), temperate steppe (STE), alpine shrubland (SHR), alpine marsh (MAR) and alpine meadow-steppe (MEA) (Table 1). The detailed information about the plant, soil and climate was introduced in the references at the last column.

Eddy covariance technique directly measures the net ecosystem $\mathrm{CO}_{2}$ exchange (NEE) between ecosystem and the atmosphere. The observed half-hourly NEE values were processed in turns by three-dimensional coordinate rotation, WPL correction, storage correction (only for the forest site) and invalid data exclusion (Yu et al., 2006). We used the method introduced by Reichstein et al. (2005) to calculate ecosystem respiration. The valid nighttime NEE (i.e., nighttime $R_{\mathrm{e}}$ when the solar elevation angle $<0$ ) and soil temperature at $5 \mathrm{~cm}$ depth were chosen to fit the activation energy kind of parameter $\left(E_{0}\right)$ for the Lloyd and Taylor model every five days using a 15-day moving window. Averaging the three $E_{0}$ with the smallest standard errors, we obtained the final $E_{0}$ for each siteyear. Then, the reference respiration $\left(R_{\text {ref }}\right)$ for the Lloyd and Taylor model was estimated every five days using a 10-day moving window. Based on the fitted model parameters ( $E_{0}$ and $\left.R_{\text {ref }}\right)$ and soil temperature at $5 \mathrm{~cm}$ depth, the Lloyd and Taylor model was executed to calculate the daytime $R_{\mathrm{e}}$ and the missing nighttime $R_{\mathrm{e}}$.

We summed the half-hourly $R_{\mathrm{e}}$ to obtain daily values, and the site-years with more than $20 \%$ of the daily $R_{\mathrm{e}}$ missing were STE in 2006, MAR in 2007 and SHR in 2009. To match the temporal resolution of the MODIS 8-day composite imagery, the daily $R_{\mathrm{e}}$ were further averaged within the same periods.

\subsection{Remote sensing data}

The MODIS data of EVI, LSWI and LST used in this study were downloaded from the University of Oklahoma Data Center [http://www.eomf.ou.edu/visualization/manual/], based on the pixels where the flux towers located (e.g., Xiao et al., 2004; Kalfas et al., 2011). The LST data is the average of daytime LST and nighttime LST. These data were all from the Terra/MODIS sensor and were 8-day composites. The spatial resolution of EVI and LSWI was $500 \mathrm{~m}$, and of LST was $1 \mathrm{~km}$.

\subsection{Parameterization and validation}

Multi-year eddy $\mathrm{CO}_{2}$ flux observations of five vegetation types from ChinaFLUX were chosen for model parameterization and validation. The site-years with more than $20 \%$ of the observed daily $R_{\mathrm{e}}$ missing (i.e., STE in 2006, MAR in 2007 and SHR in 2009) were removed from both analyses. Model parameters (i.e., $a, R_{\text {ref }}$ and $E_{0}$ ) were estimated using the nonlinear least squares (curve fitting) method with the trust-region-reflective optimization algorithm (Coleman and Li, 1996). Leave-one-out cross-validation was employed to validate the model, and the coefficient of determination $\left(r^{2}\right)$, root mean square error (RMSE) and modeling efficiency (EF) were chosen to assess the performance of the model. The 


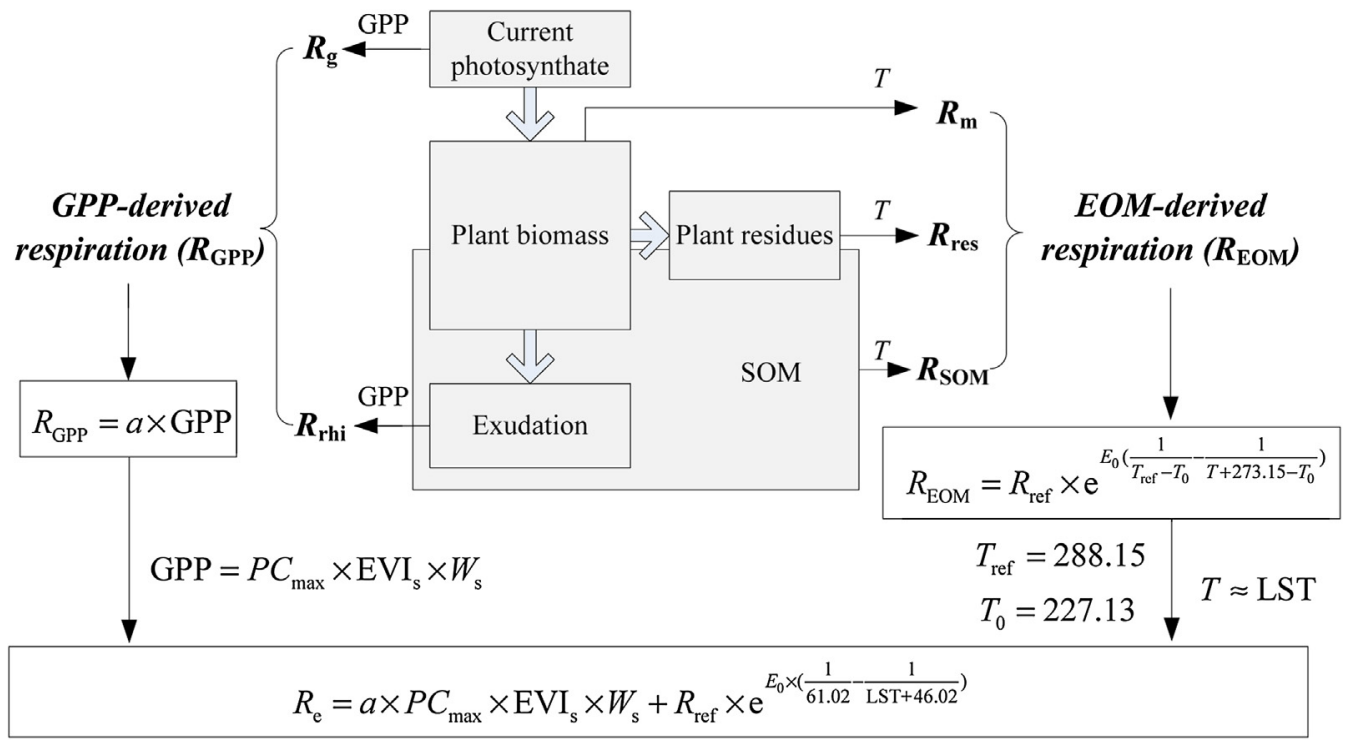

Fig. 2. Schematic diagram for the ReRSM. Description about the model parameters and variables refers to Table S3.

Table 1

A brief description of the five vegetation types.

\begin{tabular}{|c|c|c|c|c|c|c|c|c|}
\hline Code & Vegetation type & Latitude & Longitude & Site name & $\begin{array}{l}\text { Mean annual } \\
\text { temperature }\left({ }^{\circ} \mathrm{C}\right)\end{array}$ & $\begin{array}{l}\text { Mean annual } \\
\text { precipitation }(\mathrm{mm})\end{array}$ & Data period & Reference \\
\hline MF & Temperate mixed forest & 42.40 & 128.10 & Changbaishan & $0.9-4.0$ & $600-810$ & $2003-2008$ & Zhang et al. (2009) \\
\hline STE & Temperate steppe & 43.55 & 116.68 & Inner Mongolia & -0.4 & 350.9 & 2004-2008 & Wu et al. (2008) \\
\hline SHR & Alpine shrubland & 37.67 & 101.33 & Haibei & -1.7 & 600 & $2004-2011$ & Li et al. (2007) \\
\hline MAR & Alpine marsh & 37.61 & 101.31 & Haibei & -1.7 & 600 & 2004-2008 & Li et al. (2007) \\
\hline MEA & Alpine meadow-steppe & 30.85 & 91.08 & Damxung & 1.3 & 480 & 2004-2009 & Fu et al. (2009) \\
\hline
\end{tabular}

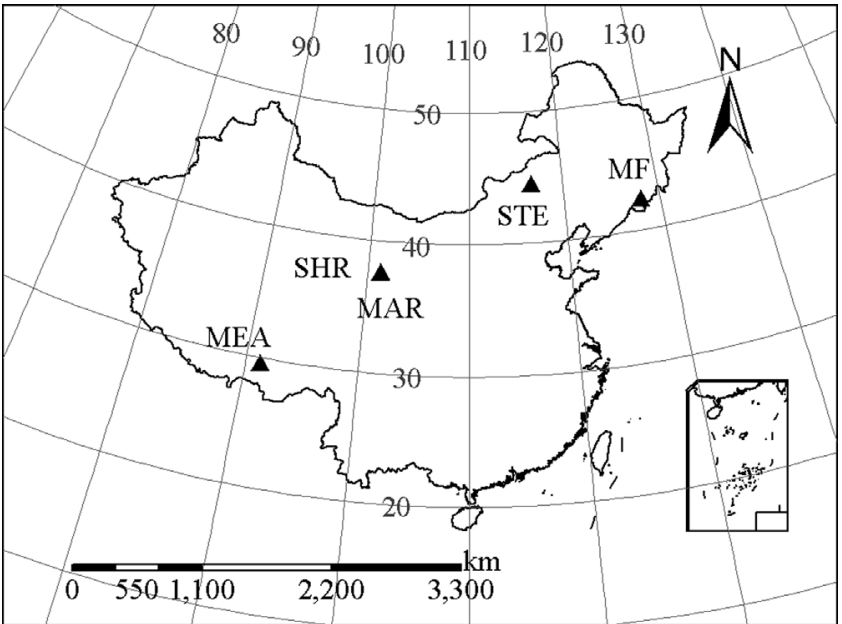

Fig. 3. Locations of the eddy-covariance towers in the five vegetation types. The flux towers at SHR and MAR locate in the same observation station. MF, temperate mixed forest; STE, temperate steppe; SHR, alpine shrubland; MAR, alpine marsh; and MEA, alpine meadow-steppe.

detailed introduction about the model validation and the statistics calculation can be found in Gao et al. (2014).

We chose a totally RS-driven $R_{\mathrm{e}}$ model, namely the RECO (Jägermeyr et al., 2014), to compare its ability in $R_{\mathrm{e}}$ estimation with that of the ReRSM in the studied five vegetation types. The RECO was conducted to estimate $R_{\mathrm{e}}$ in two ways in this study. The first is that the parameters related to the standardized respiration rate were re-fitted against the flux data for each vegetation type, while the reference respiration was directly derived from the observation due to the limited sites. The second is that all the parameters of the RECO were derived from Jägermeyr et al. (2014). According to the standard of aggregated functional biome classification in the RECO, MF belonged to the Temperate and Humid Forests (TH FOR) and the $T_{\text {ref }}$ was set to $12{ }^{\circ} \mathrm{C}$, STE belonged to the Water-Limited Non-Forested Natural Vegetation (WL GRA/CRO) and the $T_{\text {ref }}$ was set to $13^{\circ} \mathrm{C}$, and SHR, MAR and MEA belonged to the TemperatureLimited Non-Forested Natural Vegetation (TL GRA/CRO) and the $T_{\text {ref }}$ was set to $0^{\circ} \mathrm{C}$. The $r^{2}$, RMSE and EF were chosen to assess the model performance.

Since the ReRSM parameters varied among the vegetations types, we analyzed their relationships with the mean annual growing season EVI $\left(\mathrm{EVI}_{\mathrm{sm}}\right)$, LSWI $\left(\mathrm{LSWI}_{\mathrm{sm}}\right)$, daytime LST $\left(\mathrm{LST}_{\mathrm{dt}}, \mathrm{sm}\right)$, nighttime LST ( $\left.\mathrm{LST}_{\mathrm{nt}}, \mathrm{sm}\right)$ and daily LST $\left(\mathrm{LST}_{\mathrm{d}}, \mathrm{sm}\right)$, and mean annual daytime LST (LST $d$, am), daily LST $\left(\mathrm{LST}_{\mathrm{d}}\right.$, am $)$ and nighttime $\mathrm{LST}_{\mathrm{nt}}$, am, respectively. The $r^{2}$ was chosen to assess their relationships.

\section{Results}

\subsection{The ReRSM parameterization and validation}

The long-term flux tower-observed $R_{\mathrm{e}}$ of five vegetation types were chosen for the ReRSM parameterization and validation. It required the missing daily $R_{\mathrm{e}}$ to be less than $20 \%$ in each siteyear, and a total of 27 site-years met this requirement. The model parameterization showed that the ReRSM could explain approximately $74-94 \%$ of the variation in the observed $R_{\mathrm{e}}$ across five vegetation types, with the values of RMSE ranging from 0.02 to $0.06 \mathrm{~mol} \mathrm{C} \mathrm{m}^{-2} \mathrm{~d}^{-1}$ and EF ranging from 0.74 to 0.94 (Table 2). The cross-validation indicated that approximately $79-94 \%$ of the variation in the observed $R_{\mathrm{e}}$ over five vegetation types could be predicted by the ReRSM, with the values of RMSE varying from 0.02 to $0.06 \mathrm{~mol} \mathrm{C} \mathrm{m}^{-2} \mathrm{~d}^{-1}$ and EF varying from 0.65 to 0.93 . According to 
Table 2

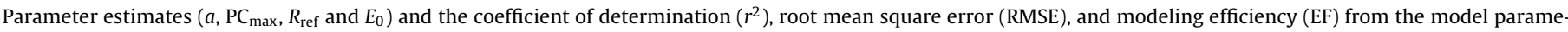

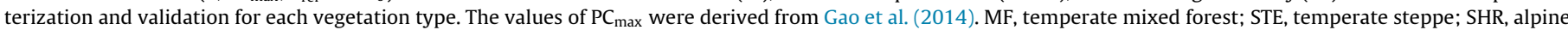
shrubland; MAR, alpine marsh; and MEA, alpine meadow-steppe. ${ }^{a}$

\begin{tabular}{|c|c|c|c|c|c|c|c|c|c|c|}
\hline \multirow[t]{2}{*}{ Site code } & \multicolumn{7}{|c|}{ Parameterization } & \multicolumn{3}{|c|}{ Validation } \\
\hline & $a$ & 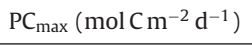 & $R_{\text {ref }}\left(\mathrm{molC} \mathrm{m}^{-2} \mathrm{~d}^{-1}\right)$ & $E_{0}(\mathrm{~K})$ & $r^{2}$ & $\operatorname{RMSE}\left(\mathrm{mol} \mathrm{C} \mathrm{m}^{-2} \mathrm{~d}^{-1}\right)$ & $\mathrm{EF}$ & $r^{2}$ & $\operatorname{RMSE}\left(\mathrm{mol} \mathrm{C} \mathrm{m}^{-2} \mathrm{~d}^{-1}\right)$ & $\mathrm{EF}$ \\
\hline MF & 0.27 & 2.61 & 0.27 & 267.30 & 0.93 & 0.06 & 0.93 & 0.94 & 0.06 & 0.92 \\
\hline STE & 0.71 & 2.18 & 0.02 & 153.53 & 0.81 & 0.03 & 0.81 & 0.85 & 0.04 & 0.65 \\
\hline SHR & 0.52 & 1.75 & 0.10 & 239.84 & 0.94 & 0.03 & 0.94 & 0.94 & 0.03 & 0.93 \\
\hline MAR & 0.39 & 1.38 & 0.10 & 97.67 & 0.88 & 0.03 & 0.88 & 0.91 & 0.03 & 0.86 \\
\hline MEA & 0.49 & 2.00 & 0.03 & 199.12 & 0.74 & 0.02 & 0.74 & 0.79 & 0.02 & 0.65 \\
\hline
\end{tabular}

a There were differences between columns $6\left(r^{2}\right)$ and $8(E F)$, but these differences were too small to be shown in the table.

the statistics from both model parameterization and validation, the ReRSM performed best in SHR, followed by MF and MAR, while it performed a little low in STE and MEA. STE locates in the semi-arid region with a mean annual precipitation of only $350.9 \mathrm{~mm}$ and the precipitation distributed unevenly across seasons and years, which may be the main reason of the low performance in this vegetation type. The most likely reason for the low performance in MEA is its very sparse vegetation cover with the maximum leaf area index (LAI ${ }_{\text {max }}$ ) of only $1.88 \mathrm{~m}^{2} \mathrm{~m}^{-2}$ (Shi et al., 2006).

Further application of the ReRSM was based on the model parameters retrieved from the site-years with less than $20 \%$ of the daily $R_{\mathrm{e}}$ missing in each vegetation type to ensure the robust of the parameters (Table 2). The ReRSM was then executed to estimate all site-years $R_{\mathrm{e}}$ across five vegetation types (a total of 30 site-years, Table 1). Results showed that the ReRSM could explain approximately $93 \%$ of the variation in the flux tower-observed $R_{\mathrm{e}}$, with the RMSE of $0.04 \mathrm{~mol} \mathrm{C} \mathrm{m}^{-2} \mathrm{~d}^{-1}$ and the EF of 0.93 (Fig. 4).

\subsection{Seasonal and interannual dynamics of the ReRSM-estimated} $R_{e}$

Using the model parameters in Table 2, the ReRSM was executed to estimate all 30 site-years $R_{\mathrm{e}}$ (Table 1 ) and then we compared the temporal dynamic in the ReRSM-estimated $R_{\mathrm{e}}$ with that in the flux tower-observed $R_{\mathrm{e}}$ (Fig. 5). In most cases, the estimated $R_{\mathrm{e}}$ is consistent with the observed $R_{\mathrm{e}}$ in terms of seasonal and interannual variation irrespective of vegetation types. The estimated maximal and minimal $R_{\mathrm{e}}$ separately matched closely with the corresponding observed $R_{\mathrm{e}}$. The agreement in seasonality and magnitude of the estimated $R_{\mathrm{e}}$ vs. the observed $R_{\mathrm{e}}$ was best in SHR (Fig. 5c), followed by MF and MAR (Fig. 5a and d). However, in several 8day periods, there were obvious gaps between the estimated $R_{\mathrm{e}}$

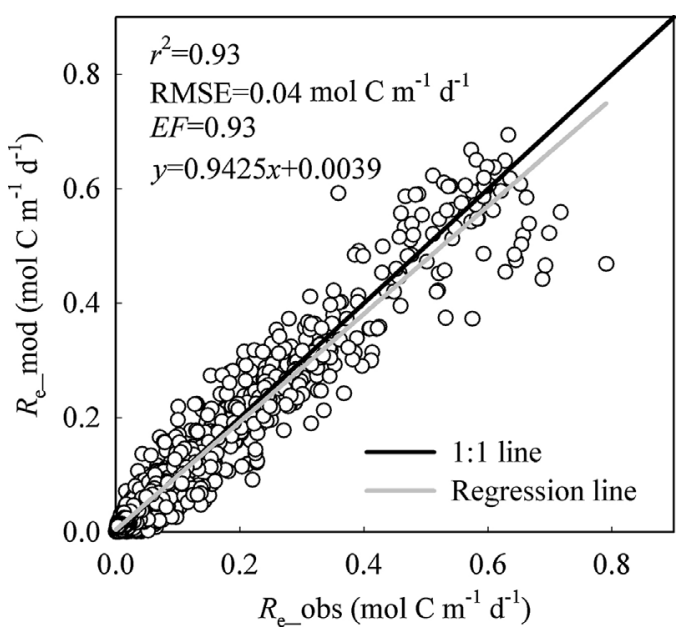

Fig. 4. Comparison between the ReRSM-estimated $R_{\mathrm{e}}$ and the flux tower-observed $R_{\mathrm{e}}$ based on an 8-day average across five vegetation types. and the observed $R_{\mathrm{e}}$. For instance, the ReRSM underestimated the observed $R_{\mathrm{e}}$ at the peak growing season of 2006 in MF (Fig. 5a) and 2008 in STE (Fig. 5b). It was probably due to the influence of water stress on photosynthesis and respiration over this time period. The ReRSM also underestimated most of the observed $R_{\mathrm{e}}$ during 2007 in MAR (Fig. 5d). This site-year had limited observations, and the eddy covariance technique for flux observation and the data processing method may introduce errors into the flux tower-observed $R_{\mathrm{e}}$.

\subsection{Compare the performance of the ReRSM with that of the RECO}

The statistics of the flux tower-observed $R_{\mathrm{e}}$ vs. RECO-estimated $R_{\mathrm{e}}$ were presented in Table 3. The RECO using the re-fitted parameters performed significantly better than using the original parameters. The values of the former RMSE and EF were respectively lower and higher than the latter ones by several orders of magnitude. When comparing the accuracy of the RECO model using the re-fitted parameters with that of the ReRSM from either parameterization or validation in Table 2, the performance of the ReRSM was comparable with that of the RECO in each vegetation type, especially in SHR and MEA. However, while the RECO had night parameters in water-limited sites and eight parameters in others, the ReRSM only had four parameters. These analyses indicated that the ReRSM is probably more appropriate in $R_{\mathrm{e}}$ estimation in our studied region.

\subsection{Variations in the ReRSM parameters}

The ReRSM parameters, i.e., $a, \mathrm{PC}_{\max }, R_{\mathrm{ref}}$ and $E_{0}$, differed among the vegetation types (Table 2 ). $\mathrm{PC}_{\max }$ had been reported to correlate linearly with the mean annual nighttime LST ( $\mathrm{LST}_{\mathrm{nt}}$, am, when the solar elevation angle $<0, r^{2}=0.86, p=0.02$, Gao et al., 2014). We further analyzed the relationships of the other model parameters with the mean annual growing season $\mathrm{EVI}\left(\mathrm{EVI}_{\mathrm{Sm}}\right)$, $\mathrm{LSWI}\left(\mathrm{LSWI}_{\mathrm{Sm}}\right)$, daytime LST ( $\left.\mathrm{LST}_{\mathrm{dt}}, \mathrm{sm}\right)$, nighttime LST $\left(\mathrm{LST}_{\mathrm{nt}}, \mathrm{sm}\right)$ and daily LST $\left(\mathrm{LST}_{\mathrm{d}}\right.$, $\mathrm{sm})$, and mean annual daytime LST ( $\left.\mathrm{LST}_{\mathrm{dt}}, \mathrm{am}\right)$, daily LST $\left(\mathrm{LST}_{\mathrm{d}}\right.$, am $)$ and nighttime $\mathrm{LST}_{\mathrm{nt}}$, am, it revealed that $E_{0}$ correlated insignificantly with any of the above satellite-derived indices. $a$ showed a negative linear relationship with $\mathrm{LSWI}_{\mathrm{Sm}}$ (Fig. 6a), and $R_{\text {ref }}$ showed positive linear relationships with both $\mathrm{EVI}_{\mathrm{Sm}}\left(r^{2}=0.84, p=0.03\right)$ and $\mathrm{LSWI}_{\mathrm{Sm}}$ (Fig. 6b), with the $r^{2}$ of $R_{\text {ref }}$ Vs. LSWI $\mathrm{LSm}_{\mathrm{sm}}$ higher than that of $R_{\mathrm{ref}} \mathrm{Vs}$. $\mathrm{EVI}_{\mathrm{sm}}$.

\section{Discussions}

\subsection{Biological basis of the ReRSM}

This study developed a solely satellite-driven $R_{\mathrm{e}}$ model (ReRSM) by assuming that ecosystem respiration $\left(R_{\mathrm{e}}\right)$ can be separated into GPP-derived respiration $\left(R_{\mathrm{GPP}}\right)$ and EOM-derived respiration $\left(R_{\mathrm{EOM}}\right)$. The ReRSM performed well in $R_{\mathrm{e}}$ estimation across five 

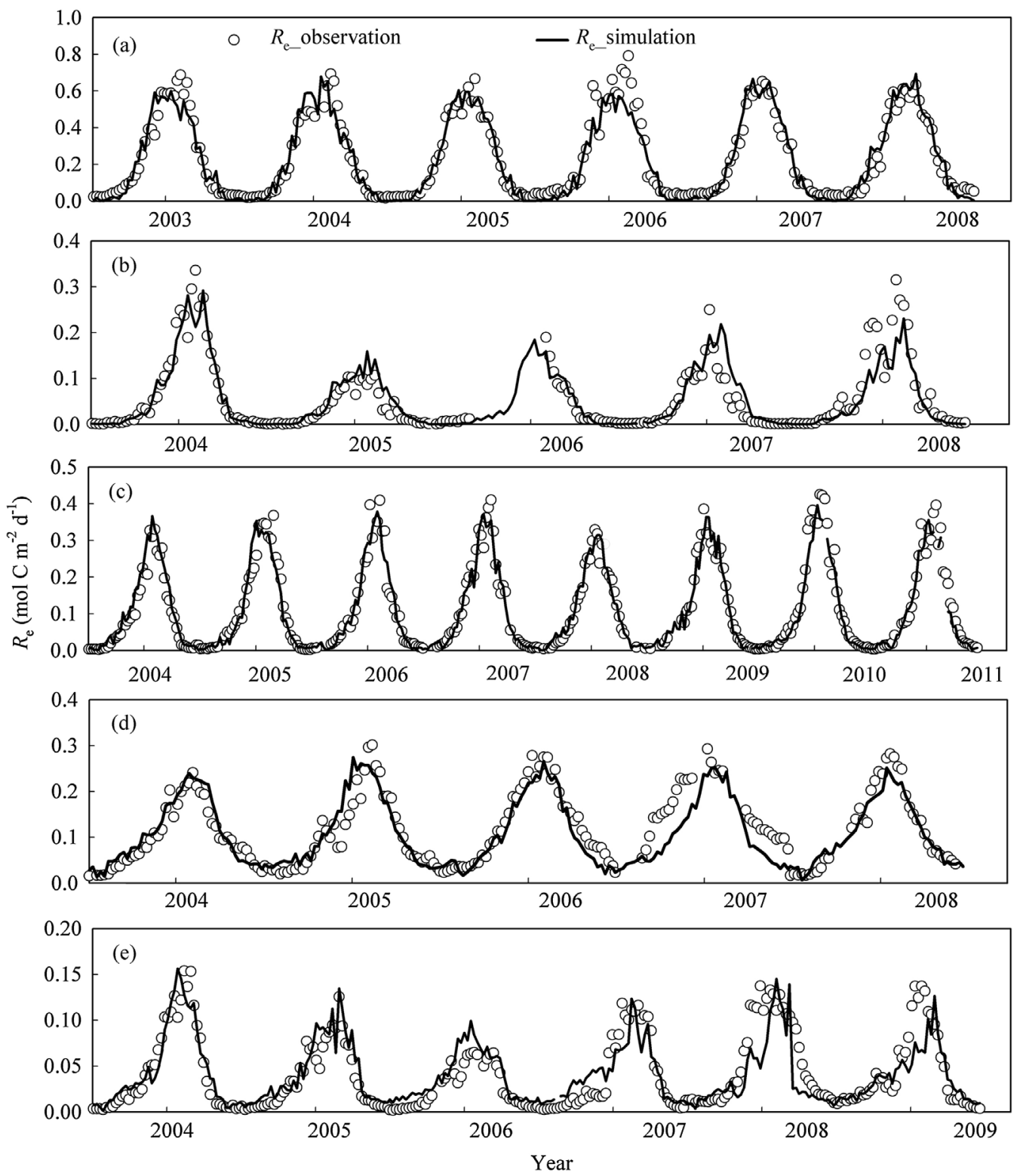

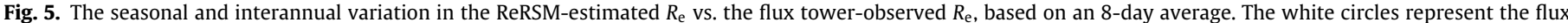

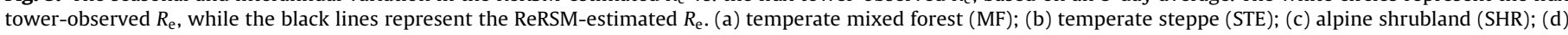
alpine marsh (MAR); and (e) alpine meadow-steppe (MEA).

Table 3

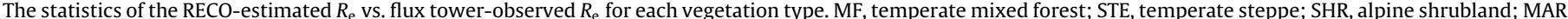

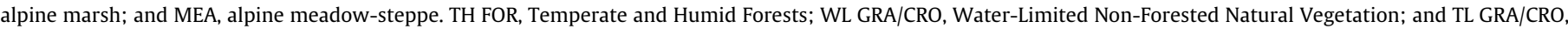
Temperature-Limited Non-Forested Natural Vegetation.

\begin{tabular}{|c|c|c|c|c|c|c|c|c|}
\hline \multirow[t]{2}{*}{ Code } & \multirow[t]{2}{*}{ Aggregated functional biomes } & \multirow[t]{2}{*}{$T_{\text {ref }}\left({ }^{\circ} \mathrm{C}\right)$} & \multicolumn{3}{|c|}{$\mathrm{RECO}^{\mathrm{a}}$} & \multicolumn{3}{|c|}{$\mathrm{RECO}^{\mathrm{b}}$} \\
\hline & & & $r^{2}$ & $\operatorname{RMSE}\left(\mathrm{mol} \mathrm{C}^{-2} \mathrm{~d}^{-1}\right)$ & $\mathrm{EF}$ & $r^{2}$ & $\operatorname{RMSE}\left(\mathrm{mol} \mathrm{C} \mathrm{m}^{-2} \mathrm{~d}^{-1}\right)$ & $\mathrm{EF}$ \\
\hline MF & TH FOR & 12 & 0.87 & 0.08 & 0.86 & 0.88 & 0.20 & 0.17 \\
\hline STE & WL GRA/CRO & 13 & 0.66 & 0.05 & 0.63 & 0.60 & 0.10 & -0.84 \\
\hline SHR & TL GRA/CRO & 0 & 0.78 & 0.06 & 0.78 & 0.56 & 0.13 & -0.16 \\
\hline MAR & TL GRA/CRO & 0 & 0.83 & 0.03 & 0.83 & 0.60 & 0.11 & -0.98 \\
\hline MEA & TL GRA/CRO & 0 & 0.46 & 0.03 & 0.30 & 0.02 & 0.06 & -1.01 \\
\hline
\end{tabular}

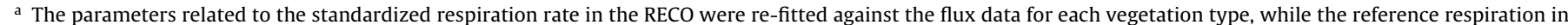
the RECO was directly derived from the observation due to the limited sites.

b All the parameters of the RECO were derived from Jägermeyr et al. (2014).

vegetation types (Table 2, Fig. 4), and clearly described the seasonal and interannual dynamics in the flux tower-observed $R_{\mathrm{e}}$ (Fig. 5).

The GPP-derived respiration in the ReRSM includes growth respiration $\left(R_{\mathrm{g}}\right)$ and rhizomicrobial respiration $\left(R_{\mathrm{rhi}}\right)$. The ReRSM employed a fraction of GPP to represent the dynamic change in $R_{\mathrm{GPP}}$, which is decided by the mechanisms behind photosynthesis and respiration. Plant photosynthesis and the process of storing the current photosynthate into its various organs necessarily need 

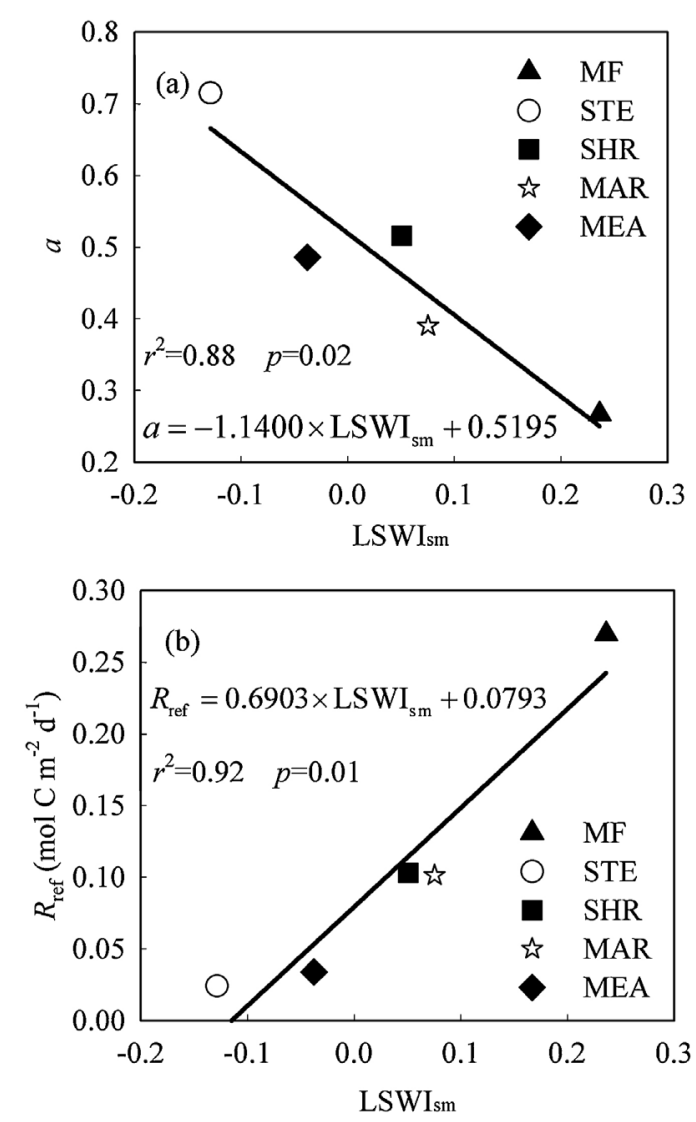

Fig. 6. The relationships (a) between $a$ and $\mathrm{LSWI}_{\mathrm{sm}}$ and (b) between $R_{\text {ref }}$ and $\mathrm{LSWI}_{\mathrm{sm}}$. $\mathrm{LSWI}_{\mathrm{sm}}$, mean annual LSWI within the growing season. MF, temperate mixed forest; STE, temperate steppe; SHR, alpine shrubland; MAR, alpine marsh; and MEA, alpine meadow-steppe.

energy supply from growth respiration at the cost of consuming some photosynthate. $R_{\mathrm{g}}$ is always a nearly constant fraction of net primary production or GPP under any environmental conditions (Amthor, 2000; Chapin et al., 2011; Piao et al., 2010). Meanwhile, part of current photosynthate is transported into roots to sustain their physiological function and then released into the rhizosphere soil in the form of root exudates. Root exudates are characteristic of low molecular weight and labile organic matter, which serve as the substrates for $R_{\text {rhi }}$ and can be rapidly respired by microorganisms in the rhizosphere. This is because available substances are the actual contributors to microbial activity (Kuzyakov and Gavrichkova, 2010), and thus rhizosphere microorganisms can be activated rapidly in the presence of root exudates (Chapin et al., 2011; Huang et al., 2012). Some studies have reported that there is a time lag between GPP and respiration response from the soil. The time lag was approximately $12.5 \pm 7.5$ (SD) h in grasses, $1-2$ days in crops, and 4-5 days in mature trees (Knohl et al., 2005; Moyano et al., 2008; Kuzyakov and Gavrichkova, 2010). Because the ReRSM was conducted at the temporal resolution of 8-day average, these kinds of time lag may introduce negligible error into the ReRSMestimated $R_{\mathrm{e}}$. Although the studies sometimes observed a link between GPP-derived respiration and temperature (Moyano et al., 2007, 2008), it is to a large extent due to the good relationship between GPP and temperature (Amthor, 2000; Chapin et al., 2011; Kuzyakov and Gavrichkova, 2010; Huang et al., 2012).

The EOM-derived respiration in the ReRSM includes maintenance respiration $\left(R_{\mathrm{m}}\right)$, microbial respiration of plant residues $\left(R_{\mathrm{res}}\right)$ and SOM decomposition $\left(R_{\mathrm{SOM}}\right)$, with the respiratory substrates derived from plant biomass, plant residues and SOM, respectively. The ReRSM chose the Lloyd and Taylor model to represent the $R_{\mathrm{EOM}}$ dynamic by assuming a same response of $R_{\mathrm{m}}, R_{\text {res }}$ and $R_{\mathrm{SOM}}$ to variation in temperature. Strictly speaking, there should be some differences among the responses due to different characteristics of their substrates. However, it was very difficult to partition these differences based on either ground observations or remote sensing data, and an excessive number of model parameters or variables also limited model application at regional scale. It was reported that there are necessarily functional linkages among plant biomass, plant residues and SOM. SOM correlates closely with soil quality (Reeves, 1997; Al-Kaisi et al., 2005), which influences plant available nutrients and the ability of soil in absorbing plant nutrients (Chen et al., 2005; Ladoni et al., 2010). Both of them primarily determine plant photosynthetic capacity (Chapin et al., 2011; Janssens et al., 2001) and plant biomass over long term periods. Plant species with high productivity are characterized by high quality of residues and high rate of residues decomposition (Chapin et al., 2011; De Deyn et al., 2008). Therefore, it was feasible to assume the identical response of $R_{\mathrm{m}}, R_{\mathrm{res}}$ and $R_{\mathrm{SOM}}$ to variation in temperature, and the high accuracy of the ReRSM in $R_{\mathrm{e}}$ estimation across five vegetation types also supported this simplification.

\subsection{Characteristics of the model parameters}

The ReRSM had four model parameters, i.e., $a, \mathrm{PC}_{\max }, R_{\mathrm{ref}}$ and $E_{0}$, all of which varied among vegetation types due to different vegetation structures, site conditions and histories (Table 2). $\mathrm{PC}_{\max }$ indicated the maximum photosynthetic capacity, which correlated

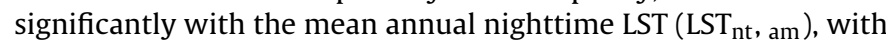
the $r^{2}$ of 0.86 (Gao et al., 2014). It may be because LST $_{n}$, am is a good indicator of the baseline temperature that decides plant phenology (Sims et al., 2008).

$R_{\text {ref }}$ represented the EOM-derived respiration at the reference temperature. The substrates for $R_{\mathrm{EOM}}$ included plant biomass, plant residues and SOM. They are all related to the long-term plant productivity as discussed above. Photosynthesis is mainly decided by canopy chlorophyll content and water conditions (Gao et al., 2014), which can be represented by EVI and LSWI, respectively. $R_{\text {ref }}$ was thus found to show significantly positive relationships with both mean annual growing season $\mathrm{EVI}\left(\mathrm{EVI}_{\mathrm{sm}}\right)$ and $\mathrm{LSWI}\left(\mathrm{LSWI}_{\mathrm{sm}}\right)$, with the $r^{2}$ of 0.84 and 0.92 , respectively (Fig. 6b). Previous studies also indicated that reference respiration depends strongly on mean annual GPP (e.g., Yuan et al., 2011), and can be estimated by LAI $\max$ (e.g., Migliavacca et al., 2011) or mean annual springtime EVI (e.g., Jägermeyr et al., 2014).

$a$ was a fraction of GPP that is transformed into GPP-derived respiration. It was observed that $a$ shows a significantly negative relationship with $\mathrm{LSWI}_{\mathrm{sm}}$, with the $r^{2}$ of 0.88 (Fig. 6a). $\mathrm{LSWI}_{\mathrm{sm}}$ represented the mean annual water conditions within the growing season, which is a main environmental factor in determining plant photosynthesis. The negative relationship between $a$ and $\mathrm{LSWI}_{\mathrm{sm}}$ may be because the plants with more water content tend to produce higher GPP and convert lower current photosynthate into GPP-derived respiration. However, the mechanisms under this relationship still need a further study.

$E_{0}$ was the activation energy kind of parameter, which can be used to represent the temperature sensitivity of respiration. There was no significant relationship between $E_{0}$ and any of the mean annual satellite-derived indices related to canopy greenness, water and temperature over either growing season or whole year. The question if the temperature sensitivity of respiration varies over time and among vegetation types is still under debate (Davidson and Janssens, 2006; Mahecha et al., 2010; Chen et al., 2010; Yvon-Durocher et al., 2012; Jägermeyr et al., 2014). Although many evidences showed that $E_{0}$ varies among compounds and decomposition of labile SOM has lower temperature sensitivity than decomposition of recalcitrant SOM (Davidson and Janssens, 


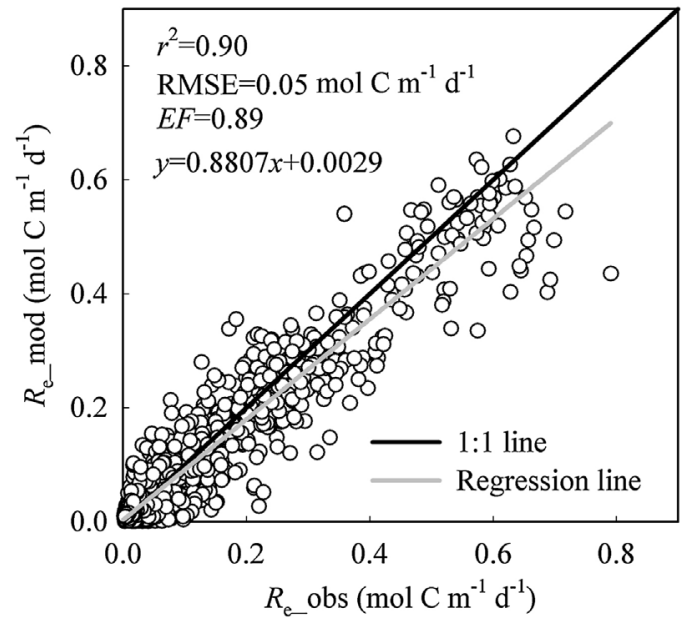

Fig. 7. Comparison between the ReRSM-estimated $R_{\mathrm{e}}$ and the flux tower-observed $R_{\mathrm{e}}$ based on an 8-day average across five vegetation types. The model parameters of the ReRSM were separately calculated from Eqs. (10)-(12).

2006), some researches reported that temperature sensitivities of respiration are remarkably similar among ecosystems (YvonDurocher et al., 2012), and can be even considered as a constant (Mahecha et al., 2010). If we assumed that $E_{0}$ is a constant of $308.56 \mathrm{~K}$ for different vegetation types (termed $E_{0}^{\prime}$ ) according to Lloyd and Taylor, (1994), the re-parameterized and re-validated statistics of the ReRSM were almost the same as those in Table 2, except the values of EF in MAR dropped separately from 0.88 and 0.86 to 0.78 and 0.76 . The re-fitted model parameters of $a$ (termed $\left.a^{\prime}\right)$ and $R_{\text {ref }}$ (termed $R_{\text {ref }}^{\prime}$ ) still correlated respectively negatively $\left(r^{2}=0.88, p=0.02\right)$ and positively $\left(r^{2}=0.96, p<0.01\right)$ with $\mathrm{LSWI}_{\mathrm{sm}}$. We chose $a_{\mathrm{GPP}}^{\prime}$ to represent the product of $\alpha^{\prime}$ and $\mathrm{PC}_{\max }$. If $\mathrm{PC}_{\max }$ was represented by the linear function of $\mathrm{LST}_{\mathrm{n}}$, am (Gao et al., 2014), the model parameters of $a_{\mathrm{GPP}}^{\prime}, R_{\mathrm{ref}}^{\prime}$ and $E_{0}^{\prime}$ can be separately expressed as follows:

$a_{\mathrm{GPP}}^{\prime}=\left(-1.2759 \times \mathrm{LSWI}_{\mathrm{sm}}+0.5079\right)$

$$
\times\left(0.1346 \times \text { LST }_{\mathrm{n} \_a m}+2.7522\right)
$$

$R_{\text {ref }}^{\prime}=0.7566 \times \mathrm{LSWI}_{\mathrm{sm}}+0.0874$

$E_{0}^{\prime}=308.56$

When using the model parameters that were calculated from Eqs. (10)-(12), the ReRSM can explain approximately $90 \%$ of the variation in the observed $R_{\mathrm{e}}$ across five vegetation types, with the RMSE of $0.05 \mathrm{~mol} \mathrm{C} \mathrm{m}^{-2} \mathrm{~d}^{-1}$ and the EF of 0.89 (Fig. 7). This result suggests the potential application of the ReRSM in estimating spatial variability of $R_{\mathrm{e}}$. However, the slope of the regression line in Fig. 7 was smaller than that in Fig. 4, which resulted in the obvious $R_{\mathrm{e}}$ underestimation in Fig. 7, especially at the higher $R_{\mathrm{e}}$ values. This was primarily due to the differences between the fitted parameters and the ones that were calculated from Eqs. (10)-(12). Furthermore, $R_{\mathrm{e}}$ is affected by a series of biological, physical and chemical processes and their interactions, which are currently not well understood (Jägermeyr et al., 2014), and therefore not being included in the model. In the further study, more factors that possibly affect the value of the model parameters should be explicitly analyzed.

\subsection{Model applications and limitations}

The ReRSM has the clear biological basis, and performed well in $R_{\mathrm{e}}$ estimation across five vegetation types in Northern China and the
Tibetan Plateau. The model is only driven by the MODIS-retrieved EVI, LSWI and LST, which facilitates the use of the ReRSM at high temporal and spatial resolution. Model comparison showed that the accuracy of the ReRSM, which had much fewer parameters, was comparable with that of the RECO in the studied five vegetation types. The ReRSM parameters also showed close relationships with the mean annual satellite-derived indices, i.e., Eqs. (10)-(12). These results indicated that the ReRSM has the potential to estimate spatially distributed $R_{\mathrm{e}}$. However, the further application of the ReRSM at regional or global scale probably has several limitations.

(1) The ReRSM probably provides poor $R_{\mathrm{e}}$ estimates under severe drought conditions because it did not contain the effect of moisture on $R_{\mathrm{e}}$. (2) The ReRSM may be incapable of estimating the pulse increase of $R_{\mathrm{e}}$ when high plant residues occur, because it did not consider the dynamic of plant residues. (3) The value of $R_{\mathrm{e}}$ was also influenced by amounts of other biotic and abiotic factors, such as nutrient availability (Fernández-Martínez et al., 2014), age of the ecosystem (Piao et al., 2010; Fernández-Martínez et al., 2014), disturbance and acclimation effects. Although the satellite-derived indices of EVI and LSWI to some extent can reflect these impacts on GPP-derived respiration, they are difficult to mirror the influences on EOM-derived respiration. Thus, more factors related to $R_{\mathrm{e}}$ should be analyzed and effectively presented in the model, and the ReRSM is only the first step of building a totally satellite-driven $R_{\mathrm{e}}$ model. Its performance in other vegetation types or regions needs to be validated in further study. Along with the development of satellite algorithms about soil moisture, plant biomass, nutrient availability, human activity, and so on, we will optimize the model structure to improve its accuracy.

\section{Acknowledgements}

This study was supported by the National Basic Research Program of China (Grant No. 2010CB833504), the CAS Strategic Priority Research Program (Grant No. XDA05050602), and the Key Program of NSFC National Natural Science Foundation of China (Grant No. 31290221). We sincerely thank the anonymous reviewers for their constructive suggestions and comments.

\section{Appendix A. Supplementary data}

Supplementary data associated with this article can be found, in the online version, at http://dx.doi.org/10.1016/j.ecolmodel. 2015.03.001.

\section{References}

Al-Kaisi, M.M., Yin, X., Licht, M.A., 2005. Soil carbon and nitrogen changes as influenced by tillage and cropping systems in some Iowa soils. Agric. Ecosyst. Environ. $105,635-647$.

Amthor, J.S., 2000. The McCree-de Wit-Penning de Vries-Thornley respiration paradigms: 30 years later. Ann. Bot. 86, 1-20.

Bader, N.E., Cheng, W., 2007. Rhizosphere priming effect of Populus fremontii obscures the temperature sensitivity of soil organic carbon respiration. Soil Biol. Biochem. 39, 600-606.

Bahn, M., Rodeghiero, M., Anderson-Dunn, M., Dore, S., Gimeno, C., Drösler, M., Williams, M., Ammann, C., Berninger, F., Flechard, C., Jones, S., Balzarolo, M., Kumar, S., Newesely, C., Priwitzer, T., Raschi, A., Siegwolf, R., Susiluoto, S., Tenhunen, J., Wohlfahrt, G., Cernusca, A., 2008. Soil respiration in European grasslands in relation to climate and assimilate supply. Ecosystems 11, 1352-1367.

Bond-Lamberty, B., Thomson, A., 2010. Temperature-associated increases in the global soil respiration record. Nature 464, 579-582.

Chapin III, F.S., Matson, P.A., Vitousek, P.M., 2011. Principles of Terrestrial Ecosystem Ecology, 2nd ed. Springer Science + Business Media, New York.

Chen, F., Kissel, D.E., West, L.T., Rickman, D., Luvall, J.C., Adkins, W., 2005. Mapping surface soil organic carbon for crop fields with remote sensing. J. Soil Water Conserv, 60, 51-57.

Chen, S., Huang, Y., Zou, J., Shen, Q., Hu, Z., Qin, Y., Chen, H., Pan, G., 2010. Modeling interannual variability of global soil respiration from climate and soil properties. Agric. For. Meteorol. 150, 590-605. 
Coleman, T.F., Li, Y., 1996. An interior, trust region approach for nonlinear minimization subject to bounds. SIAM J. Optim. 6, 418-445.

Davidson, E.A., Janssens, I.A., 2006. Temperature sensitivity of soil carbon decomposition and feedbacks to climate change. Nature 440, 165-173.

De Deyn, G.B., Cornelissen, J.H.C., Bardgett, R.D., 2008. Plant functional traits and soil carbon sequestration in contrasting biomes. Ecol. Lett. 11, 516-531.

Dilkes, N.B., Jones, D.L., Farrar, J., 2004. Temporal dynamics of carbon partitioning and rhizodeposition in wheat. Plant Physiol. 134, 706-715.

Fernández-Martínez, M., Vicca, S., Janssens, I.A., Sardans, J., Luyssaert, S., Campioli, M., Chapin III, F.S., Ciais, P., Malhi, Y., Obersteiner, M., Papale, D., Piao, S., Reichstein, M., Rodà, F., Peñuelas, J., 2014. Nutrient availability as the key regulator of global forest carbon balance. Nat. Clim. Chang. 4, 471-476.

Frank, A.B., Liebig, M.A., Hanson, J.D., 2002. Soil carbon dioxide fluxes in northern semiarid grasslands. Soil Biol. Biochem. 34, 1235-1241.

Fu, Y., Zheng, Z., Yu, G., Hu, Z., Sun, X., Shi, P., Wang, Y., Zhao, X., 2009. Environmental influences on carbon dioxide fluxes over three grassland ecosystems in China. Biogeosciences 6, 2879-2893.

Gao, Y., Yu, G., Yan, H., Zhu, X., Li, S., Wang, Q., Zhang, J., Wang, Y., Li, Y., Zhao, L., Shi, P., 2014. A MODIS-based Photosynthetic Capacity Model to estimate gross primary production in Northern China and the Tibetan Plateau. Remote Sens. Environ. 148, 108-118.

Gaumont-Guay, D., Black, T.A., Barr, A.G., Jassal, R.S., Nesic, Z., 2008. Biophysical controls on rhizospheric and heterotrophic components of soil respiration in a boreal black spruce stand. Tree Physiol. 28, 161-171.

Gilmanov, T.G., Tieszen, L.L., Wylie, B.K., Flanagan, L.B., Frank, A.B., Haferkamp, M.R., Meyers, T.P., Morgan, J.A., 2005. Integration of $\mathrm{CO}_{2}$ flux and remotely-sensed data for primary production and ecosystem respiration analyses in the Northern Great Plains: potential for quantitative spatial extrapolation. Glob. Ecol. Biogeogr. 14, 271-292.

Gitelson, A.A., Viña, A., Verma, S.B., Rundquist, D.C., Arkebauer, T.J., Keydan, G., Leavitt, B., Ciganda, V., Burba, G.G., Suyker, A.E., 2006. Relationship between gross primary production and chlorophyll content in crops: implications for the synoptic monitoring of vegetation productivity. J. Geophys. Res. Atmos. 111, D08S11, http://dx.doi.org/10.1029/2005JD006017.

Gitelson, A.A., Peng, Y., Masek, J.G., Rundquist, D.C., Verma, S., Suyker, A., Baker, J.M., Hatfield, J.L., Meyers, T., 2012. Remote estimation of crop gross primary production with Landsat data. Remote Sens. Environ. 121, 404-414.

Gomez-Casanovas, N., Matamala, R., Cook, D.R., Gonzalez-Meler, M.A., 2012. Net ecosystem exchange modifies the relationship between the autotrophic and heterotrophic components of soil respiration with abiotic factors in prairie grasslands. Glob. Chang. Biol. 18, 2532-2545.

Heinemeyer, A., Ineson, P., Ostle, N., Fitter, A., 2006. Respiration of the external mycelium in the arbuscular mycorrhizal symbiosis shows strong dependence on recent photosynthates and acclimation to temperature. New Phytol. 171, $159-170$.

Heinemeyer, A., Hartley, I.P., Evans, S.P., Carreira De La Fuente, J.A., Ineson, P., 2007. Forest soil $\mathrm{CO}_{2}$ flux: uncovering the contribution and environmental responses of ectomycorrhizas. Glob. Chang. Biol. 13, 1786-1797.

Huang, N., Niu, Z., 2013. Estimating soil respiration using spectral vegetation indices and abiotic factors in irrigated and rainfed agroecosystems. Plant Soil 367, 535-550.

Huang, N., Niu, Z., Zhan, Y., Xu, S., Tappert, M.C., Wu, C., Huang, W., Gao, S., Hou, X., Cai, D., 2012. Relationships between soil respiration and photosynthesis-related spectral vegetation indices in two cropland ecosystems. Agric. For. Meteorol. 160, 80-89.

Jägermeyr, J., Gerten, D., Lucht, W., Hostert, P., Migliavacca, M., Nemani, R., 2014. A high-resolution approach to estimating ecosystem respiration at continental scales using operational satellite data. Glob. Chang. Biol. 20, $1191-1210$.

Janssens, I.A., Lankreijer, H., Matteucci, G., Kowalski, A.S., Buchmann, N., Epron, D., Pilegaard, K., Kutsch, W., Longdoz, B., Grünwald, T., Montagnani, L., Dore, S., Rebmann, C., Moors, E.J., Grelle, A., Rannik, Ü., Morgenstern, K., Oltchev, S., Clement, R., Guð̈mundsson, J., Minerbi, S., Berbigier, P., Ibrom, A., Moncrieff, J., Aubinet, M., Bernhofer, C., Jensen, N.O., Vesala, T., Granier, A., Schulze, E.D., Lindroth, A., Dolman, A.J., Jarvis, P.G., Ceulemans, R., Valentini, R., 2001. Productivity overshadows temperature in determining soil and ecosystem respiration across European forests. Glob. Chang. Biol. 7, 269-278.

Kalfas, J.L., Xiao, X., Vanegas, D.X., Verma, S.B., Suyker, A.E., 2011. Modeling gross primary production of irrigated and rain-fed maize using MODIS imagery and $\mathrm{CO}_{2}$ flux tower data. Agric. For. Meteorol. 151, 1514-1528.

Knohl, A., Werner, R.A., Brand, W.A., Buchmann, N., 2005. Short-term variations in $\delta^{13} \mathrm{C}$ of ecosystem respiration reveals link between assimilation and respiration in a deciduous forest. Oecologia 142, 70-82.

Kuzyakov, Y., Cheng, W., 2001. Photosynthesis controls of rhizosphere respiration and organic matter decomposition. Soil Biol. Biochem. 33, 1915-1925.

Kuzyakov, Y., Cheng, W., 2004. Photosynthesis controls of $\mathrm{CO}_{2}$ efflux from maize rhizosphere. Plant Soil 263, 85-99.

Kuzyakov, Y., Gavrichkova, O., 2010. Review: Time lag between photosynthesis and carbon dioxide efflux from soil: a review of mechanisms and controls. Glob. Chang. Biol. 16, 3386-3406.

Ladoni, M., Bahrami, H.A., Alavipanah, S.K., Norouzi, A.A., 2010. Estimating soil organic carbon from soil reflectance: a review. Precis. Agric. 11, 82-99.

Larsen, K.S., Ibrom, A., Beier, C., Jonasson, S., Michelsen, A., 2007. Ecosystem respiration depends strongly on photosynthesis in a temperate heath. Biogeochemistry $85,201-213$
Li, Z., Yu, G., Xiao, X., Li, Y., Zhao, X., Ren, C., Zhang, L., Fu, Y., 2007. Modeling gross primary production of alpine ecosystems in the Tibetan Plateau using MODIS images and climate data. Remote Sens. Environ. 107, 510-519.

Lloyd, J., Taylor, J.A., 1994. On the temperature dependence of soil respiration. Funct. Ecol. 8, 315-323.

Mahecha, M.D., Reichstein, M., Carvalhais, N., Lasslop, G., Lange, H., Seneviratne S.I., Vargas, R., Ammann, C., Arain, M.A., Cescatti, A., Janssens, I.A., Migliavacca, M., Montagnani, L., Richardson, A.D., 2010. Global convergence in the temperature sensitivity of respiration at ecosystem level. Science 329 838-840.

Matías, L., Castro, J., Zamora, R., 2012. Effect of simulated climate change on soil respiration in a Mediterranean-type ecosystem: rainfall and habitat type are more important than temperature or the soil carbon pool. Ecosystems 15, 299-310.

Migliavacca, M., Reichstein, M., Richardson, A.D., Colombo, R., Sutton, M.A., Lasslop, G., Tomelleri, E., Wohlfahrt, G., Carvalhais, N., Cescatti, A., Mahecha, M.D., Montagnani, L., Papale, D., Zaehle, S., Arain, A., Arneth, A., Black, T.A., Carrara, A., Dore S., Gianelle, D., Helfter, C., Hollinger, D., Kutsch, W.L., Lafleur, P.M., Nouvellon, Y., Rebmann, C., Da Rocha, H.R., Rodeghiero, M., Roupsard, O., SebastiÀ, M.-T., Seufert, G., Soussana, J.-F., Van Der Molen, M.K., 2011. Semiempirical modeling of abiotic and biotic factors controlling ecosystem respiration across eddy covariance sites. Glob. Chang. Biol. 17, 390-409.

Mildrexler, D.J., Zhao, M., Running, S.W., 2011. A global comparison between station air temperatures and MODIS land surface temperatures reveals the cooling role of forests. J. Geophys. Res. 116, G03025, http://dx.doi.org/10.1029/ 2010JG001486.

Moyano, F.E., Kutsch, W.L., Schulze, E.-D., 2007. Response of mycorrhizal, rhizosphere and soil basal respiration to temperature and photosynthesis in a barley field. Soil Biol. Biochem. 39, 843-853.

Moyano, F.E., Kutsch, W.L., Rebmann, C., 2008. Soil respiration fluxes in relation to photosynthetic activity in broad-leaf and needle-leaf forest stands. Agric. For. Meteorol. 148, 135-143.

Olofsson, P., Lagergren, F., Lindroth, A., Lindström, J., Klemedtsson, L., Kutsch, W., Eklundh, L., 2008. Towards operational remote sensing of forest carbon balance across Northern Europe. Biogeosciences 5, 817-832.

Piao, S., Luyssaert, S., Ciais, P., Janssens, I.A., Chen, A., Cao, C., Fang, J., Friedlingstein, P., Luo, Y., Wang, S., 2010. Forest annual carbon cost: a global-scale analysis of autotrophic respiration. Ecology 91, 652-661.

Rahman, A.F., Sims, D.A., Cordova, V.D., EI-Masri, B.Z., 2005. Potential of MODIS EVI and surface temperature for directly estimating per-pixel ecosystem C fluxes. Geophys. Res. Lett. 32, L19404, http://dx.doi.org/10.1029/2005GL024127.

Reeves, D.W., 1997. The role of soil organic matter in maintaining soil quality in continuous cropping systems. Soil Tillage Res. 43, 131-167.

Reichstein, M., Tenhunen, J.D., Roupsard, O., Ourcival, J.M., Rambal, S., Dore, S., Valentini, R., 2002. Ecosystem respiration in two Mediterranean evergreen Holm Oak forests: drought effects and decomposition dynamics. Funct. Ecol. 16, 27-39.

Reichstein, M., Rey, A., Freibauer, A., Tenhunen, J., Valentini, R., Banza, J., Casals, P., Cheng, Y., Grünzweig, J.M., Irvine, J., Joffre, R., Law, B.E., Loustau, D., Miglietta F., Oechel, W., Ourcival, J.-M., Pereira, J.S., Peressotti, A., Ponti, F., Qi, Y., Rambal S., Rayment, M., Romanya, J., Rossi, F., Tedeschi, V., Tirone, G., Xu, M., Yakir, D. 2003. Modeling temporal and large-scale spatial variability of soil respiration from soil water availability, temperature and vegetation productivity indices. Glob. Biogeochem. Cycles 17, 1104, http://dx.doi.org/10.1029/2003GB002035.

Reichstein, M., Falge, E., Baldocchi, D., Papale, D., Aubinet, M., Berbigier, P., Bernhofer, C., Buchmann, N., Gilmanov, T., Granier, A., Grünwald, T., Havránková, K. Ilvesniemi, H., Janous, D., Knohl, A., Laurila, T., Lohila, A., Loustau, D., Matteucci, G., Meyers, T., Miglietta, F., Ourcival, J.-M., Pumpanen, J., Rambal, S., Rotenberg, E., Sanz, M., Tenhunen, J., Seufert, G., Vaccari, F., Vesala, T., Yakir, D., Valentini, R., 2005. On the separation of net ecosystem exchange into assimilation and ecosystem respiration: review and improved algorithm. Glob. Chang. Biol. 11, 1424-1439.

Rey, A., Pegoraro, E., Tedeschi, V., De Parri, I., Jarvis, P.G., Valentini, R., 2002. Annua variation in soil respiration and its components in a coppice oak forest in Centra Italy. Glob. Chang. Biol. 8, 851-866.

Running, S.W., Nemani, R.R., Heinsch, F.A., Zhao, M., Reeves, M., Hashimoto, H., 2004 A continuous satellite-derived measure of global terrestrial primary production. Bioscience 54, 547-560.

Schubert, P., Eklundh, L., Lund, M., Nilsson, M., 2010. Estimating northern peatland $\mathrm{CO}_{2}$ exchange from MODIS time series data. Remote Sens. Environ. 114 $1178-1189$

Shi, P., Sun, X., Xu, L., Zhang, X., He, Y., Zhang, D., Yu, G., 2006. Net ecosystem $\mathrm{CO}_{2}$ exchange and controlling factors in a steppe-Kobresia meadow on the Tibetan Plateau. Sci. China Ser. D: Earth Sci. 49 (Supp. II), 207-218.

Sims, D.A., Rahman, A.F., Cordova, V.D., El-Masri, B.Z., Baldocchi, D.D., Bolstad, P.V., Flanagan, L.B., Goldstein, A.H., Hollinger, D.Y., Misson, L., Monson, R.K., Oechel, W.C., Schmid, H.P., Wofsy, S.C., Xu, L., 2008. A new model of gross primary productivity for North American ecosystems based solely on the enhanced vegetation index and land surface temperature from MODIS. Remote Sens. Environ. 112, 1633-1646.

Tang, J., Baldocchi, D.D., Xu, L., 2005. Tree photosynthesis modulates soil respiration on a diurnal time scale. Glob. Chang. Biol. 11, 1298-1304.

Tang, X., Wang, Z., Liu, D., Song, K., Jia, M., Dong, Z., Munger, J.W., Hollinger, D.Y., Bolstad, P.V., Goldstein, A.H., Desai, A.R., Dragoni, D., Liu, X., 2012. Estimating the net ecosystem exchange for the major forests in the northern United States by integrating MODIS and AmeriFlux data. Agric. For. Meteorol. 156, 75-84.

Trumbore, S., 2006. Carbon respired by terrestrial ecosystems - recent progress and challenges. Glob. Chang. Biol. 12, 141-153. 
Ueyama, M., Harazono, Y., Ichii, K., 2010. Satellite-based modeling of the carbon fluxes in mature black spruce forests in Alaska: a synthesis of the eddy covariance data and satellite remote sensing data. Earth Interact., 14, http://dx.doi.org/10.1175/2010EI319.1.

Valentini, R., Matteucci, G., Dolman, A.J., Schulze, E.D., Rebmann, C., Moors, E.J., Granier, A., Gross, P., Jensen, N.O., Pilegaard, K., Lindroth, A., Grelle, A., Bernhofer, C., Grünwald, T., Aubinet, M., Ceulemans, R., Kowalski, A.S., Vesala, T., Rannik, Ü., Berbigier, P., Loustau, D., Gudmundsson, J., Thorgeirsson, H., Ibrom, A., Morgenstern, K., Clement, R., Moncrieff, J., Montagnani, L., Minerbi, S., Jarvis, P.G., 2000. Respiration as the main determinant of carbon balance in European forests. Nature 404, 861-865.

Vourlitis, G.L., Verfaillie, J., Oechel, W.C., Hope, A., Stow, D., Engstrom, R., 2003. Spatial variation in regional $\mathrm{CO}_{2}$ exchange for the Kuparuk River Basin. Alaska over the summer growing season. Glob. Chang. Biol. 9, 930-941.

Waksman, S.A., Gerretsen, F.C., 1931. Influence of temperature and moisture upon the nature and extent of decomposition of plant residues by microorganisms. Ecology 12, 33-60.

Wu, W., Wang, S., Xiao, X., Yu, G., Fu, Y., Hao, Y., 2008. Modeling gross primary production of a temperate grassland ecosystem in Inner Mongolia, China, using MODIS imagery and climate data. Sci. China Ser. D: Earth Sci. 51, 1501-1512.

Wu, C., Niu, Z., Gao, S., 2010. Gross primary production estimation from MODIS data with vegetation index and photosynthetically active radiation in maize. J. Geophys. Res. Atmos. 115, D12127, http://dx.doi.org/10.1029/2009JD013023.

Xiao, X., Hollinger, D., Aber, J., Goltz, M., Davidson, E.A., Zhang, Q., Moore, B., 2004. Satellite-based modeling of gross primary production in an evergreen needleleaf forest. Remote Sens. Environ. 89, 519-534.

Xiao, J.F., Zhuang, Q.L., Baldocchi, D.D., Law, B.E., Richardson, A.D., Chen, J.Q., Oren, R., Starr, G., Noormets, A., Ma, S.Y., Verma, S.B., Wharton, S., Wofsy, S.C., Bolstad, P.V. Burns, S.P., Cook, D.R., Curtis, P.S., Drake, B.G., Falk, M., Fischer, M.L., Foster, D.R. Gu, L.H., Hadley, J.L., Hollinger, D.Y., Katul, G.G., Litvak, M., Martin, T.A., Matamala,
R., McNulty, S., Meyers, T.P., Monson, R.K., Munger, J.W., Oechel, W.C.U., Schmid, K.T.P., Scott, H.P., Sun, R.L., Suyker, G., Torn, A.E.M.S., 2008. Estimation of net ecosystem carbon exchange for the conterminous United States by combining MODIS and AmeriFlux data. Agric. For. Meteorol. 148, 1827-1847.

Yu, G., Wen, X., Sun, X., Tanner, B.D., Lee, X., Chen, J., 2006. Overview of ChinaFLUX and evaluation of its eddy covariance measurement. Agric. For. Meteorol. 137 125-137.

Yuan, W.P., Liu, S., Zhou, G.S., Zhou, G.Y., Tieszen, L.L., Baldocchi, D., Bernhofer, C. Gholz, H., Goldstein, A.H., Goulden, M.L., Hollinger, D.Y., Hu, Y., Law, B.E., Stoy P.C., Vesala, T., Wofsy, S.C., 2007. Deriving a light use efficiency model from eddy covariance flux data for predicting daily gross primary production across biomes. Agric. For. Meteorol. 143, 189-207.

Yuan, W., Luo, Y., Li, X., Liu, S., Yu, G., Zhou, T., Bahn, M., Black, A., Desai, A.R. Cescatti, A., Marcolla, B., Jacobs, C., Chen, J., Aurela, M., Bernhofer, C., Gielen, B. Bohrer, G., Cook, D.R., Dragoni, D., Dunn, A.L., Gianelle, D., Grünwald, T., Ibrom, A., Leclerc, M.Y., Lindroth, A., Liu, H., Marchesini, L.B., Montagnani, L., Pita, G. Rodeghiero, M., Rodrigues, A., Starr, G., Stoy, P.C., 2011. Redefinition and globa estimation of basal ecosystem respiration rate. Glob. Biogeochem. Cycles 25, GB4002, http://dx.doi.org/10.1029/2011GB004150.

Yvon-Durocher, G., Caffrey, J.M., Cescatti, A., Dossena, M., del Giorgio, P., Gasol, J.M. Montoya, J.M., Pumpanen, J., Staehr, P.A., Trimmer, M., Woodward, G., Allen, A.P. 2012. Reconciling the temperature dependence of respiration across timescales and ecosystem types. Nature 487, 472-476.

Zhang, J., Hu, Y., Xiao, X., Chen, P., Han, S., Song, G., Yu, G., 2009. Satellite-based estimation of evapotranspiration of an old-growth temperate mixed forest. Agric. For. Meteorol. 149, 976-984

Zhou, Z., Jiang, L., Du, E., Hu, H., Li, Y., Chen, D., Fang, J., 2013. Temperature and substrate availability regulate soil respiration in the tropical mountain rainforests, Hainan Island, China. J. Plant Ecol. 6, 325-334. 